\title{
Ideologi dalam Struktur Tema-Rema dan Transitivitas Lagu Campursari Sesidheman
}

\author{
Kristiandi ${ }^{1}$, Teguh Sarosa ${ }^{2}$, Sumarlam ${ }^{3}$ \\ 1,2 English Education Department, Faculty of Teacher Training and Education, \\ Universitas Sebelas Maret, Surakarta, Indonesia \\ ${ }^{3}$ Javanese Department, Faculty of Cultural Sciences, \\ Universitas Sebelas Maret, Surakarta, Indonesia
}

\section{Article Info}

Article history:

Submitted May 23, 2020

Revised June 29, 2020

Accepted Sept 09, 2020

Published Nov 02, 2020

\section{Keywords:}

Critical discourse analysis

Ideology

Campursari

Song lyric

\begin{abstract}
This article reveals the ideology proposed in the campursari song entitled Sesidheman written by Ki Dalang H Sukron Suwondo. This Critical Discource Analisys (CDA) is based on Halliday's Systemic Functional Linguictics (SFL) as its analytical framework and Fairclough's Dialectical Relational model as the conceptual framework. Conceptually, the analysis of the song refers to the three dimensions of CDA proposed by Fairclough. The ThemeRheme and transitivity systems are used to describe the micro structure of the text, interpret the text, and explain the relations between interations contained in the lyric of the song as refected in the text with the social practices associated with the lyric of the song. The Theme-Rheme structure of the song Sesidheman lyric consists of macro theme of the Bawa, the intro part of the lyric, and hyper-theme in the main lyric. The mscro theme structure and the transitivity of the Bawa part depict the background, process, and the effect of the actions committed by the characters in the story contained in the lyric. The hypertheme structure and the transitivity of the main part of the lyric depict the decision making, the cuases of decision making, and the consequence resulted in the decision making, which includes the material and non-material values. The transitivity of the song lyric is dominated by material process depicting the action committed by the male and female characters of the song lyric. As a form of of social practice and a means to shape society, the campurari song Sesidheman depicts the ideology proposed by the song writer upon the phenomena happening in the community surrounding shadow puppet artits (traditional Javanese song singers and pupeteers).
\end{abstract}

\section{Corresponding Author:}

Kristiandi

English Education Department, Faculty of Teacher Training and Education,

Universitas Sebelas Maret

Jl. Ir. Sutami 36 A, Kentingan, Surakarta, Indonesia.

Email: kristiandi@staff.uns.ac.id

\section{PENDAHULUAN}

Istilah campursari terdiri dari dua kata: campur dan sari. Campur bermakna pembauran, penggabungan, pemaduan antara dua entitas menjadi satu kesatuan yang utuh. Sementara itu, istilah sari artinya sesuatu yang indah dan harmonis. Jadi istilah campursari artinya pemaduan atau akulturasi antara musik pentatonis ( gamelan) dan musik diatonis yang menghasilkan jenis musik baru yang selaras, indah, dan harmoni. 
Sejarah campursari dimulai pada tahun 1993 ketika Manthous mendirikan grup musik campursari Maju Lancar di Gunung Kidul. Lagu campursari pada saat itu berupa langgam Jawa seperti Kutut Manggung, Anting-anting, Yen Ing Tawang Ana Lintang, dan langgam Jawa lainnya. Untuk mempopulerkan lagu campursari, Manthous meminta Waldjinah, seorang penyanyi keroncong terkenal, untuk menyanyikan lagu campursari. Penyanyi lain yang membawakan lagu campursari Mantous dan menjadi populer diantaranya adalah Sunyahni, Sulasmi, dan Nurafni Octavia. Campursari ini menjadi tenar pada tahun 1994 dengan semakin banyak para penyanyi yang menyanyikan lagu ini dan juga semakin banyaknya permintaan masyarakat, khusus menengah ke bawah, terhadap lagu ini dalam berbagai pentas musik.

Seiring dengan perkembangan jaman, tema-tema lagu campursari juga menyesuaikan dengan perkembangan budaya di masyarakat. Lagu campursari bisa digunakan untuk menggambarkan fenomena yang terjadi di masyarakat. Pencipta sekaligus penyanyi campursari yang mengambil tema tentang fenomena yang terjadi di masyarat diantaranya yaitu Didi Kempot, Cak Diqin, dan Dimas Tejo. Dalam menciptakan lagu campusari mereka menggunakan bahasa Jawa yang lugas, yaitu bahasa Jawa yang digunakan oleh masyarakat Jawa dalam komunikasi sehari-hari. Hanya sedikit pencipta lagu campursari yang menggunakan bahasa Jawa yang halus dalam lirik lagunya. Salah satu pencipta lagu tersebut yaitu Ki Sukron Suwondo yang menciptakan lagu Sesidheman. Tak mengherankan mengapa Ki Sukron Suwondo banyak menggunakan bahasa Jawa yang halus karena dia adalah seorang seniman dalang.

Penelitian mengenai musik campursari sudah dikaji oleh beberapa peneliti. Wiyoso (2007) mengkaji musik campur dari sisi proses terbentuknya musik tersebut melalui proses akulturasi antara musik langgam keroncong, gamelan Jawa, jaipongan dan dangdut. Supanggah (2003) menyatakan bahwa musik campursari merupakan perpaduan antara dua elemen musik, yaitu elemen musik keroncong dan elemen musik gamelan Jawa. Senada dengan Wiyoso dan Supanggah, Wadiyo $(2002,2004)$ dan Wadiyo et al (2011, 2012) menyatakan bahwa musik campursari merupakan campuran permainan instrumen musik tradisional Jawa dan instrumen musik modern. Semula musik ini dianggap sebagai musik Jawa yang jelek dan mendapatkan banyak kritik dari akademisi tentang bentuk garapan musik tersebut. Namun kemudian banyak muncul kelompok musik campursari di masyarakat yang secara tidak langsung mendukung keberadaan musik campursari ciptaan Manthous tersebut. Suranto (2019) mengkaji campursari dari sisi penyelarasan musiknya antara slendro, pelog, dan juga jenis musik diatonis dari barat. Sistem pelarasan dalam campursari sebagian menggunakan tangga nada diatonis dan mengubah nada-nada pada gamelan menyesuaikan dengan keyboard atau alat-alat musik dengan sistem pelarasan diatonis yang lain. Laksono (2008) mengkaji tentang tokoh di balik campursari yaitu sosok Manthous sebagai pioneer dalam campursari baik sebagai pencipta lagu maupun sebagai penyanyi. Manthous merupakan cikal bakal berdiri dan berkembangnya musik campursari di wilayah Indonesia.

Pengkajian musik campursari sebagai wahana untuk memberikan pendidikan moral kepada masyarakat dilakukakan oleh beberapa peneliti. Widiyono (2013) mengkaji campursari sebagai sarana untuk menanamkan pendidikan karakter di sekolah melalui pengenalan budaya dan kesenian. Dengan pemahaman isi dan makna pada tembang campursari lewat pembelajaran formal dan nonformal diharapkan nilai-nilai yang 
terkandung di dalamnya dapat berperan dalam pembentukan karakter bangsa. Chandra (2017) melakukan penelitian dengan pendekatan semiotika untuk mengkaji aspek moral yang terdapat dalam lirik lagu campursari Jawa Timur yang mencermati krisis moral dari sisi seksualitas, perselingkuhan, poligami, dan perendahan martabat orang lain. Penelitian lagu campursari Seshideman ini mempunyai aspek kajian yang berbeda yaitu mengkaji aspek moral kehidupan masyarakat khususnya terkait hubungan asmara terselubung dari pendekatan LSF.

Lagu campursari merupakan produk karya seni yang hadir dalam masyarakat Jawa, terutama Jawa Tengah dan Jawa Timur. Umumnya lagu campursari diciptakan untuk menghibur masyarakat pendengar dengan menyuguhkan tema yang dekat dengan selera dan dunia masyarakat pendengarnya. Tema yang paling umum disajikan dalam lagu campursari adalah tentang cinta antara pria dan wanita. Tema tentang cinta antara pria dan wanita ini diambil dari konteks masyarakat penikmat lagu campursari, sehingga lagu campursari merupakan sesuatu yang sangat familiar bagi masyarakat penggemarnya. Sebagai produk karya seni yang mengangkat tema kehidupan masyarakat penggemarnya, lagu campursari dapat dilihat sebagai konstruksi dari realitas sosial yang tertuang dalam bentuk lagu. Konstruksi realitas sosial ini dikemas dalam syair lagu dan musik yang digemari masyarakat sehingga lagu campursari senantiasa dekat dengan kehidupan masyarakat penggemarnya.

Menurut Collins Dictionary, lagu adalah bagian dari musik, biasanya menggunakan teks verbal, diciptakan untuk dinyanyikan, terutama ditujukan untuk penampilan solois. Lirik atau syair lagu dikategorikan sebagai karya seni tertulis yang bentuknya mirip dengan puisi. Sebagai suatu karya seni yang mirip puisi, lirik lagu dapat dipandang sebagai suatu karya sastra. Menurut Greenlaw dalam Wellek \& Warren (1977:11) karya sastra mencakupi segala sesuatu yang tertulis yang berkaitan dengan sejarah peradaban. Karya sastra tidak hanya memiliki kaitan yang erat dengan sejarah peradaban manusia, karya sastra juga identik dengan peradaban manusia itu sendiri. Dilihat dari definsi ini, lirik lagu campursari identik dengan peradaban masyarakat yang menjadi konteks lahirnya lirik suatu lagu campursari.

Penelitian mengenai musik campursari sudah dikaji oleh beberapa peneliti. Wiyoso (2007) mengkaji musik campur dari sisi proses terbentuknya musik tersebut melalui proses akulturasi antara music langgam keroncong,gamelan Jawa, jaipongan dan dangdut. Laksono (2008) mengkaji tentang tokoh di balik campursari yaitu sosok Manthous sebagai pioner dalam campursari baik sebagai pencipta lagu maupun sebagai penyanyi. Widiyono (2013) mengkaji campursari sebagai sarana untuk menanamkan pendidikan karakter di sekolah melalui pengenalan budaya dan kesenian. Chandra (2017) melakukan penelitian dengan pendekatan semiotika untuk mengkaji aspek moral yang terdapat dalam lirik lagu campursari Jawa Timur yang mencermati krisis moral dari sisi seksualitas, perselingkuhan, poligami, dan perendahan martabat orang lain. Penelitian lagu campursari Seshideman ini mempunyai aspek kajian yang berbeda yaitu mengkaji aspek moral kehidupan masyarakat khususnya terkait hubungan asmara terselubung dari pendekatan LSF. 


\section{TEORI DAN METODOLOGI}

Fairclough dalam Sumarlam (2013) menjelaskan sebuah teks dipandang bermuatan ideologis (teks ideologis) apabila teks tersebut memuat konsep perjuangan atas hegemoni yang dicapai oleh suatu teks. Teks ideologis dipandang sebagai teks yang menunjukkan ketidaksetaraan dan ketidakseimbangan sehingga perlu dilakukan perubahan terhadap kekeliruan pandangan mengenai kurang pentingnya bahasa bagi penciptaan, pemeliharaan, dan perubahan sosial. Tujuan akhir gagasan Fairclough yaitu kesetaraan penggunaan bahasa yang mampu menciptakan kehidupan masyarakat yang harmonis.

Pendekatan AWK Fairclough yang berciri kognitif sosial memfokuskan pada 3 dimensi analisis suatu teks yaitu pertama, dimensi teks yang mencakup bentuk dan makna linguistik seperti modalitas, majas, kesantunan dalam berinteraksi, topik, tema dan kohesi; kedua, dimensi praktik kewacanaan yang meliputi proses produksi teks oleh penutur,mitra tutur, dan media serta proses komunikasi atau interpretasi teks oleh publik yang dilakukan secara intertekstualitas (bertujuan untuk menspesifikasi distribusikan, rangkaian teks melalui proses perpindahan tipe teks dan transformasi teks baik secara konvensional maupun inovatif) dan antartekstualitas (menjelaskan apakah suatu teks disusun oleh beberapa teks dan menelaah tipe aktifitas, model, dan genre suatu teks serta menganalisis koherensi untuk menginterpretasikan teks situasional (menggambarkan emosi, perasaan, dan kondisi mental psikologis para partisipan dalam kondisi kejadian tertentu), institusional (menggambarkan situasi dan kondisi institusi, lembaga, kelompok masyarakat yang diatur oleh norma tertentu), dan sosial (menggambarkan kondisi menyeluruh kehidupan sosial suatu masyarakat yang diatur relasi sosial berdasarkan kedudukan, fungsi dan peran individu dalam kehidupan sosial). Dimensi yang ketiga yaitu dimensi praktis sosial budaya terkait kerangka analisis teks secara situasional (situasi yang menggambarkan perasaan atau kondisi para partisipan), institusional (kondisi kelompok masyarakat yang diatur oleh norma), dan sosial (kondisi menyeluruh kehidupan sosial suatu masyarakat yang diatur oleh relasi sosial berdasarkan kedudukan, fungsi, dan peran individu dalam kehidupan sosial).

Dengan menggunakan model AWK Fairclough sebagai kerangka konsep, teks lirik lagu campursari Sesidheman ini dianalisis berdasarkan Linguistik Sistemik Fungsional (LSF). LSF memiliki karakteristik yang sama dengan AWK, yaitu bahwa sebagaimana AWK, LSF memandang bahasa sebagai bentuk konstruksi praktik sosial, bahasa dan konteks saling mempengaruhi, dan bahasa dalam konteks sosial budaya mampu menciptakan praktik sosial baru. Bahasa merupakan praktik sosial (Halliday, 1994) yang memiliki hubungan dialektik dengan sisi-sisi masalah sosial (Fairclough, 1995). Hubungan dialektik ini bermakna bahwa dalam satu sisi bahasa terbentuk oleh praktik sosial dan di sisi lain bahasa membentuk suatu praktik sosial. Bahasa tidak hanya memiliki fungsi referensial, namun juga fungsional.

Kress (1990) menjelaskan bahwa dalam hal bahasa dan konteks merupakaan satu kesatuan yang tidak terpisahkan, sebenarnya ada ideologi yang menjadi penghubung antara wacana dengan masyarakat melalui bahasa yang digunakan. Van Dijk (2004) menyatakan bahwa ideologi merupakan suatu bentuk paham yang terdiri atas paham yang dianut seseorang, nilai, tujuan, dan antisipasi. Mazid (1999) membagi ideologi menjadi ideologi netral dan ideologi kritis. Ideologi netral adalah pemikiran-pemikiran 
yang digunakan oleh seseorang atau suatu kelompok dalam memahami apa yang terjadi di sekelilingnya, sedangkan ideologi kritis merupakan otoritas dan manipulasi yang diterapkan oleh seseorang atau suatu kelompok untuk mempengaruhi paham dan tindakan orang atau kelompok lain. Peran bahasa dalam merealisasikan ideologi ini digambarkan oleh Van Dijk sebagai perisai yang sekaligus menjadi senjata. Sebagai perisai, bahasa bisa direalisasikan untuk mengurangi kekurangan diri sendiri dan mengurangi kelebihan pihak lain. Sebagai senjata, bahasa direalisasikan untuk memperkuat kelebihan diri sendiri dan memperjelas kekurangan pihak lain.

Lagu Sesidheman merupakan lagu campursari yang sangat populer di daerah Jawa, khususnya Jawa Tengah dan Jawa Timur. Lagu ini dibuat oleh Sukron Suwondo, seorang dalang senior yang cukup terkenal di daerah Jawa Timur khususnya Blitar. Keluarga Sukron merupakan keluarga seniman, kedua anaknya Ki Cahyo Kuntadi dan Ki Anom Dwijo Kangkow juga berprofesi sebagai dalang dan menantunya berprofesi sebagai sebagai sinden. Lagu ini diciptakan oleh Sukron Suwondo di TMII pada hari Minggu. Pada waktu itu beliau baru saja takziyah seorang temannya yang meninggal di daerah Tangerang. Beliau sendiri yang memimpin keberangkatan jenazah untuk dimakamkan di daerah Tulungagung.

Lagu ini menceritakan kisah asmara tersembunyi antara bendoro dan seorang gadis gunung yang cantik jelita. Karena cintanya yang sangat mendalam, bendoro ini rela untuk membohongi keluarganya, anak dan istri serta kehilangan kehormatannya. Bahkan bendoro ini juga rela membelikan rumah seisinya kepada 'dyah sulistya' yang sudah meluluhlantakkan hatinya. Lagu ini sesungguhnya mengandung pesan moral yang dalam yang dibuat untuk temannya yang sudah meninggal tersebut. Pesan moral tersebut muncul untuk melawan fenomena pergeseran norma susila yang terjadi di masyarakat dewasa ini. Fenomena tersebut bukan merupakan hal yang tabu lagi dan banyak terjadi di masyarakat dan juga di kalangan seniman dalang.

\section{Metode}

Secara konseptual, analsis data dilaksanakanan berdasarkan kerangka analisis AWK Fairclough (1995) yang terdiri atas tiga dimensi, yaitu: (1) wacana sebagai teks; (2) wacana sebagai interaksi antara orang-orang yang terlibat dalam pembuatan dan interpretasi teks; dan (3) wacana sebagai bagian dari aksi sosial. Berdasarkan ketiga dimensi wacana tersebut, analisis dilaksanakan dalam tiga tahap: (1) analisis teks lirik lagu Sesidheman yang mencakupi analisis Tema-Rema dan transitivitas; (2) interpretasi teks dengan fokus pada hubungan antara teks dengan interaksi pencipta lirik lagu Sesidheman dengan msyarakat lingkungannya dan interpretasi penggemar lagu tersebut; dan (3) memaparkan hubungan antara interaksi teks, orang-orang yang terlibat dan konteks sosial budaya di mana lirik lagu Sesidheman diciptakan dan dinikmati penggemarnya.

Data yang dianalisis terdiri dari teks lirik lagu campursari Sesidheman dan informasi yang diperoleh dari petikan wawancara dengan pencipta lagu, pengamatan atas penikmat lagu, dan ahli wacana dalam antropologi budaya Jawa. Analisis struktur TemaRema teks dilaksanakan untuk mengetahui bagaimana pesan dan identitas disampaikan melalui struktur lirik lagu. Analisis Transitivitas teks dilaksanakan untuk mengetahui makna representasi dan relasi yang tersurat dalam lirik lagu. Interpretasi hubungan teks 
dengan pencipta dan penikmat lagu Sesidheman dilaksanakan dengan menggunakan dialektika relasional dengan fokus produksi lirik lagu. Tahap terakhir, tahap eksplanasi proses diskursif, dilaksanakan dengan menginterpretasikan perasaan penikmat lagu terkait ideologi yang terkandung dalam lirik lagu dalam konteks wacana sebagai praktik sosial budaya. Data yang dianalisis meliputi interprestasi hasil wawancara, hasil observasi, dan kajian norma sosil-budaya yang menjadi konteks penciptaan lirik lagu campursari Sesidheman dan sekaligus konteks distribusi lagu tersebut. Tahap ini menghubungkan bagaimana lirik lagu campursari Sesidheman berhubungan dengan konteks makro, yaitu konteks sosial-budaya.

\section{HASIL DAN PEMBAHASAN}

Struktur Tema-Rema

Bawa

\begin{tabular}{|c|c|c|}
\hline 1 & Wiwitane & $\begin{array}{l}\text { [SANG DYAH AYU] handherek sang pekik, priya } \\
\text { bagus kang olah budaya }\end{array}$ \\
\hline & Tema 1: Topikal Bermarkah & Rema 1 \\
\hline \multirow[t]{2}{*}{2} & [SANG DYAHAYU] & Sowan menyang kutha gedhe \\
\hline & [Tema 2: Topikal Tak Bermarkah]* & Rema 2 \\
\hline \multirow[t]{2}{*}{3} & Bendara & $\begin{array}{l}\text { terus kayungyun selendhang kuning kang saking } \\
\text { wukir }\end{array}$ \\
\hline & Tema 3: Topikal Tak Bermarkah. & Rema 3 \\
\hline \multirow[t]{2}{*}{4} & [SANADYAN] Swara [SANG DYAHAYU] & kurang premana \\
\hline & Tema 4: Topikal Tak Bermarkah & Rema 4 \\
\hline \multirow[t]{2}{*}{5} & ning [SANG DYAHAYU] & wasis angungrung \\
\hline & Tema 5: Tekstual, [Topikal Tak Bermarkah]* & Rema 5 \\
\hline \multirow[t]{2}{*}{6} & [SANG DYAH AYU] & Ngrungrung marang bendara \\
\hline & Tema 6: [Topikal Tak Bermarkah]* & Rema 6 \\
\hline \multirow[t]{2}{*}{7} & Sang dyah ayu & pijer ngincangake alis \\
\hline & Tema 7: Topikal Tak Bermarkah & Rema 7 \\
\hline \multirow[t]{2}{*}{8} & Trus [SANG DYAHAYU] & tresna sesidheman \\
\hline & Tema 8: Tekstual, [Topikal Tak Bermarkah]* & Rema 8 \\
\hline
\end{tabular}

Lirik:

\begin{tabular}{|c|l|l|}
\hline 9 & Luwih becik patenana & timbang pepisahan mring dyah kang sulistya \\
\hline & $\begin{array}{l}\text { Tema 9: Interpersonal, Topikal Tak } \\
\text { Bermarkah }\end{array}$ & Rema 9 \\
\hline 10 & Tak rewangi & samudana marang kulawarga, garwa lan pra putra \\
\hline & Tema 10: Topikal Tak Bermarkah & Rema 10 \\
\hline 11 & Liwat kincanging alismu & $\begin{array}{l}\text { [KOWE:SANG DYAH AYU] kuwasa hangglandhang, } \\
\text { rasaning atiku }\end{array}$ \\
\hline & Tema 11: Topikal Bermarkah & Rema 11 \\
\hline 12 & Nadyan wus lingsir yuswaku, & aku isih mampu ngladeni solahmu \\
\hline 13 & Tema 12: Topikal Bermarkah & Rema 12 \\
\hline & $\begin{array}{l}\text { Mangka kowe } \\
\text { bema 13: Interpersonal, Topikal Tak }\end{array}$ & bocah nggunung \\
\hline
\end{tabular}




\begin{tabular}{|c|c|c|}
\hline 14 & Nadyan bocah nggunung & [KOWE: SANG DYAH AYU] kaduga hanyrimpung \\
\hline & Tema 14: Topikal Bermarkah & Rema 14 \\
\hline \multirow[t]{2}{*}{15} & Liwa ragaku & kok kurung, \\
\hline & Tema 15: Topikal Tak Bermarkah & Rema 15 \\
\hline \multirow[t]{2}{*}{16} & kahormatan & mamprung \\
\hline & Tema 16: Topikal Tak Bermarkah & Rema 16 \\
\hline \multirow[t]{2}{*}{17} & (KAHORMATAN) & rubuh ngarep pinjung \\
\hline & [Tema 17: Topikal Tak Bermarkah]* & Rema 17 \\
\hline \multirow[t]{2}{*}{18} & Urip ana kutha gedhe, & kowe tak tukokke omah sak isine \\
\hline & Tema 18: Topikal Bermarkah & Rema 18 \\
\hline \multirow[t]{2}{*}{19} & $\underline{\text { Kowe }}$ & $\begin{array}{l}\text { aba apa wae nadyan sesidheman mesthi tak } \\
\text { wujudke }\end{array}$ \\
\hline & Tema 19: Topikal Tak Bermarkah & Rema 19 \\
\hline
\end{tabular}

Teks lirik lagu Sesidheman terdiri atas dua bagian, yaitu bawa (intro) dan isi. Bawa berisi ringkasan lirik yang menceritakan awal mula terjadinya kisah cinta (perselingkuhan) antara karakter yang digambarkan di dalam lirik lagu. Bagian ini terdiri atas 12 larik yang secara sintaktik terdiri atas 8 klausa deklaratif berdasarkan analisis Tema-Rema dan transitivitas. Isi lirik terdiri atas 16 larik yang disusun dari 11 klausa deklaratif berdasarkan analisis struktur Tema-Rema dan 15 klausa berdasarkan analisis transitivitas. Secara keseluruhan jumlah klausa adalah 19 klausa bersasarkan analisis struktur Tema-Rema dan 23 klausa berdasarkan analisis transitivitas.

Ringkasan ini dibangun dengan struktur Tema-Rema yang dimulai dengan Tema klausa pertama (T1) topikal bermarkah (wiwitane: pada mulanya) dalam klausa material yang diikuti Rema (R1) yang menceritakan apa yang terjadi pada awal cerita yaitu (sang Dyah Ayu) handherek sang pekik..... Klausa ini berupa klausa material dengan subyek pelaku (aktor) yang tidak dinyatakan, yaitu sang Dyah Аyu. Klausa selanjutnya, klausa kedua, adalah klausa material dengan subyek pelaku yang tidak dinyatakan dan mengacu pada subyek pelaku yang tidak dinyatakan pada R1 (sang Dyah Ayu). Dengan demikian, Tema klausa kedua (T2) bisa dipahami sebagai Tema topikal tak bermarkah yang tidak dinyatakan secara eksplisit. Klausa ketiga dimulai dengan Tema baru (T3) yaitu topikal tak bermarkah (bendara: majikan) yang merupakan subyek pelaku dan merujuk pada R1 (sang Pekik: si pria tampan) dan diikuti dengan Rema (R3) yang merujuk pada sang Dyah Ayu (selendang kuning). Klausa keempat merupakan keterangan perlawanan ([Sanadyan] swara [sang Dyah Ayu] kurang premana: [Meskipun] suara [sang Dyah Ayu] tidak bagus) yang diikuti klausa kelima (klausa utama) dengan subyek pelaku yang tidak disebutkan (sang Dyah Ayu) yang pandai menggoda hati sang Pekik. Tema klausa keempat (T4) adalah topikal tak bermarkah, yaitu swara (sang Dyah Ayu) yang diikuti R4, yang menerangkan kualitas suara yang tidak bagus. Tema klausa kelima (T5) adalah topikal tak bermarkah yang tidak dinyatakan secara eksplisit, yaitu sang Dyah Ayu, yang diikuti R5. Klausa keenam menegaskan klausa sebelumnya dengan mengulangi klausa sebelumnya, namun Tema klausa ini tidak dinyatakan. Tema klausa ini (T6) bisa dipahami sebagai Tema topikal tak bermarkah yang merujuk pada subyek pelaku pada T5 (sang Dyah Ayu) yang juga tidak dinyatakan secara eksplisit. Rema klausa keenam (R6) merujuk pada T3 
(bendara). Klausa ketujuh dimulai dengan Tema topikal tak bermarkah (T7) yang berfungsi sebagai subyek pelaku. Tema ini dinyatakan secara eksplisit dan merujuk pada T6, T5, T4, T2, R3, dan R1. Klausa kedelapan dimulai lagi dengan Tema implisit (T8) yang bisa dipahami sebagai Tema topikal tak bermarkah yang merujuk pada sang Dyah Ayu.

Ringkasan lagu campursari Sesidheman ini menceritakan awal mula terjadinya perselingkuhan antara sang Dyah Ayu (karakter wanita) dan sang Pekik (karakter pria). Penceritaan awal perselingkuhan ini berpusat pada karakter wanita yang secara implisit dinyatakan pada Tema topikal tak bermarkah (Tema sebagai subyek: T2, T4, T5, T6, T8), diungkapkan secara ekplisit pada Tema topikal tak bermarkah (T7) dan secara implisit sebagai subyek pelaku (R1, R3). Dari konfigurasi struktur Tema_Rema kedelapan klausa pada bagian Bawa, pesan yang menggambarkan awal mula kejadian, proses yang terjadi selanjutnya sampai pada klausa yang menyatakan bahwa hubungan kedua karakter dalam lirik lagu berakhir pada hubungan perselingkuhan didominasi dengan Tema tak bermarkah implisit dan subyek pelaku implisit pada Rema. Dengan konfigurasi ini, subyek pelaku yang merupakan pelaku kunci cerita dalam lagu campursari ini tidak dinyatakan secara ekplisit, namun bisa dipahami secara implisit. Ini menunjukan kecenderungan penulis untuk tidak menyatakan siapa sebenarnya karakter yang dimaksud dalam teks secara langsung. Penyebutan karakter kunci secara eksplisit hanya terjadi pada klausa ketujuh dalam bentuk Tema topikal tak bermarkah.

Isi lagu campursari Sesidheman dimulai dengan klausa material dengan Tema interpersonal (Luwih becik) dan Tema topikal tak bermarkah (T9) dalam bentuk sufiks na yang menyatakan subyek pelaku yang melekat pada verba patenana. T9 ini dilanjutkan dengan R9 di mana bagian dari R9 (dyah kang sulistya: sang Dyah Ayu) adalah entitas yang sama dengan $\mathrm{T} 9$ yang direalisasikan dengan sufiks ' $n a$ ' yang merupakan pronomina yang merujuk pada sang Dyah Ayu. Klausa kesepuluh adalah klausa material yang dimulai dengan Tema topikal tak bermarkah (T10) yang merujuk pada sang Pekik, dan dilanjutkan dengan R10. Tema pada klausa kesebelas (T11) adalah Tema topikal bermarkah yang merujuk pada apa yang dilakukan sang Dyah Ayu melalui penggunaan sufiks mu pada alismu, yang kemudian dilanjutkan dengan R11. Tema pada klausa kedua belas (T12) adalah topikal bermarkah (Nadyan wus lingsir yuswaku: Meskipun aku sudah berusia lanjut), yang dilanjutkan dengan Rema 12 yang menyatakan bahwa aku (sang Pekik) masih mampu mengimbangi sang Dyah Ayu yang dinyatakan dengan sufiks mu pada solahmu. Selanjutnya Tema pada klausa ketiga belas (T13) adalah Tema interpersonal dan topikal tak bermarkah yang merujuk pada sang Dyah Ayu melalui penggunaan pronomina kowe, dan T13 dilanjutkan dengan R13 dalam klausa relasional. Tema klausa keempat belas (T14) adalah Tema topikal tidak tak bermarkah yang berupa sirkumstan konsesi atas klausa pada Rema yang mengikutinya (R14), yang menyatakan bahwa sang Dyah Ayu mampu menjerat hati sang Pekik. Tema klausa kelima belas (T15) adalah Tema topikal tak bermarkah yang merujuk sang Pekik, yang dilanjutkan dengan R15 yang merujuk pada sang Dyah Ayu melalui penggunaan prefiks kok. Demikian pula halnya dengan Tema pada klausa keenam belas (T16), Tema topikal tak bermarkah pada klausa ini juga merujuk pada sang Pekik, yang dilanjutkan dengan R16. Pada klausa ketujuh belas, Tema tidak dinyatakan secara eksplisit, namun dari konteks wacana dapat dipahami bahwa T17 secara implisit merujuk pada sang Pekik, dan R17 merujuk pada sang Dyah Ayu melalui penggunaan metafora pinjung. Tema pada klausa kedelapan belas (T18) adalah Tema 
topikal bermarkah yang berupa keterangan tujuan, yang dilanjutkan dengan R18 yang berupa klausa pasif dengan subyek (klien) sang Dyah Ayu yang diungkapkan dalam bentuk pronimina kowe. Isi lagu ini diakhiri dengan klausa kesembilan belas dengan Tema topikal tak bermarkah (T19) yang merujuk pada sang Dyah Ayu, yang dilanjutkan dengan R19 tentang keinginan sang Dyah Ayu.

Konfigurasi struktur Tema-Rema isi lagu campursari Sesidheman merujuk pada sang Dyah Ayu yang selalu tidak disebut secara eksplisit. Sang Dyah Ayu hanya sekali disebut secara eksplisit pada T7 pada bagian bawa, dan selanjutnya dirujuk dengan sufiks na pada T9, sufiks mu pada T11 dan R12, pronomina kowe pada T13, prefiks kok pada R15, metafora pinjung pada R17, pronomina kowe pada R18, dan pronomina kowe pada T19. Dengan demikian, karakter wanita yang merupakan karakter kunci yang dikenalkan oleh pencipta lagu sebagai sang Dyah Ayu ini tidak pernah disebutkan secara eksplisit pada isi lagu. Karakter kunci ini hanya sekali disebut pada T7 pada bagian bawa. Penyebutan karakter kunci secara eksplisit pada klausa ketujuh saja ini memberikan kesan bahwa pencipta lagu tidak ingin secara vulgar menyoroti karakter kunci wanita, meskipun karakter ini memegang peranan utama dalam cerita yang terkandung dalam syair lagu campursari ini. Hal yang sama juga terjadi pada penyebutan karakter kunci pria yang secara konteks daat dipahami sebagai seorang dalang. Karakter pria ini disebut secara implisit dengan metafora priya bagus kang olah budaya pada R1 dan bendara (T3 \& R6) di bagian Bawa. Pada bagian isi, karakter pria ini tidak pernah disebut secara eksplisit. Karakter pria hanya dirujuk dengan pronomina yang berupa prefiks tak (T10, R18, R19), sufiks $k u$ (R11, T12, T15), dan pronomina $a k u$ (R12).

\section{Struktur Transitivitas}

\begin{tabular}{|c|c|c|c|c|}
\hline \multicolumn{5}{|c|}{ Bawa } \\
\hline 1 & Wiwitane, & [SANG DYAH AYU] & handherek & $\begin{array}{l}\text { sang pekik, priya bagus } \\
\text { kang olah budaya }\end{array}$ \\
\hline & $\begin{array}{l}\text { Sirkumstan: } \\
\text { Lokasi: Waktu }\end{array}$ & [Aktor]* & Prosess: Material & $\begin{array}{l}\text { Sirkumstan: } \\
\text { Lokasi: Tempat }\end{array}$ \\
\hline 2 & [SANG DYAH AYU] & Sowan & \multicolumn{2}{|l|}{ menyang kutha gedhe } \\
\hline & [Aktor $^{*}$ & Prosess: Material & \multicolumn{2}{|c|}{ Sirkumstan: Lokasi: Tempat } \\
\hline 3 & Bendara & terus kayungyun & \multicolumn{2}{|c|}{ selendhang kuning kang saking wukir } \\
\hline & Goal & Prosess: Material & \multicolumn{2}{|l|}{ Aktor } \\
\hline \multirow[t]{2}{*}{4} & [SANADYAN] & Swara & (kurang premana) & kurang premana \\
\hline & [Konjungsi] $^{*}$ & Penyandang & Proses: Relasional & Atribut \\
\hline \multirow[t]{2}{*}{5} & ning & [SANG DYAH AYU] & (wasis angungrung) & wasis angungrung \\
\hline & Konjungsi & [Penyandang]* & Proses: Relasional & Atribut \\
\hline \multirow[t]{2}{*}{6} & [SANG DYAH AYU] & $\begin{array}{l}\text { Ngrungrung } \\
\text { marang }\end{array}$ & \multicolumn{2}{|l|}{ bendara } \\
\hline & [Aktor]* & Prosess: Material & \multicolumn{2}{|l|}{ Goal } \\
\hline \multirow[t]{2}{*}{7} & Sang dyah ayu & $\begin{array}{l}\text { pijer } \\
\text { ngincangake }\end{array}$ & \multicolumn{2}{|l|}{ alis } \\
\hline & Aktor & Proses: Material & \multicolumn{2}{|l|}{ Goal } \\
\hline \multirow[t]{2}{*}{8} & Trus & [SANG DYAH AYU] & tresna & sesidheman \\
\hline & Konjungsi & [Aktor] $^{*}$ & Prosess: Material & Sirkumstan: Cara: Kualitas \\
\hline
\end{tabular}


Lirik:

\begin{tabular}{|c|c|c|c|c|c|}
\hline 9 & Luwih becik & patena(na) & \multicolumn{3}{|l|}{$n a$} \\
\hline & Comment Adjunct & Prosess: Material & \multicolumn{3}{|l|}{ Aktor } \\
\hline \multirow[t]{2}{*}{10} & timbang & {$[A K U]$} & pepisahan & \multicolumn{2}{|c|}{ mring dyah kang sulistya } \\
\hline & Konjungsi & [Aktor $^{*}$ & Prosess: Material & \multicolumn{2}{|c|}{ Sirkumstan: Lokasi: Tempat } \\
\hline \multirow[t]{2}{*}{11} & Tak & rewangi samudana & \multicolumn{3}{|c|}{ marang kulawarga, garwa lan pra putra } \\
\hline & Aktor & Prosess: Material & \multicolumn{3}{|l|}{ Skop: Entitas } \\
\hline \multirow[t]{2}{*}{12} & $\begin{array}{l}\text { Liwat kincanging } \\
\text { alismu }\end{array}$ & $\begin{array}{l}\text { [KOWE: SANG DYAH } \\
\text { AYU] }\end{array}$ & $\begin{array}{l}\text { kuwasa } \\
\text { hangglandhang }\end{array}$ & \multicolumn{2}{|l|}{ rasaning atiku } \\
\hline & $\begin{array}{l}\text { Sirkumstan: } \\
\text { Cara: Alat }\end{array}$ & [Aktor $]^{*}$ & Prosess: Material & \multicolumn{2}{|l|}{ Skop: entitas } \\
\hline \multirow[t]{2}{*}{13} & Nadyan & wus lingsir & (wus lingsir) & \multicolumn{2}{|l|}{ yuswaku, } \\
\hline & Konjungsi & Atribut & $\begin{array}{l}\text { Proses: } \\
\text { Relasional }\end{array}$ & \multicolumn{2}{|l|}{ Penyandang } \\
\hline \multirow[t]{2}{*}{14} & $a k u$ & $\begin{array}{l}\text { isih mampu } \\
\text { ngladeni }\end{array}$ & \multicolumn{3}{|l|}{ solahmu } \\
\hline & Aktor & Proses: Material & \multicolumn{3}{|l|}{ Skop: entitas } \\
\hline \multirow[t]{2}{*}{15} & Mangka & kowe & $\begin{array}{l}\text { (bocah } \\
\text { nggunung) }\end{array}$ & \multicolumn{2}{|l|}{ bocah nggunung } \\
\hline & Konjungsi & Penyandang & $\begin{array}{l}\text { Proses: } \\
\text { Relasional }\end{array}$ & \multicolumn{2}{|l|}{ Atribut } \\
\hline \multirow[t]{2}{*}{16} & Nadyan & $\begin{array}{l}\text { [KOWE: SANG DYAH } \\
\text { AYU] }\end{array}$ & $\begin{array}{l}\text { (bocah } \\
\text { nggunung) }\end{array}$ & \multicolumn{2}{|l|}{ bocah nggunung, } \\
\hline & Konjungsi & [Penyandang]* & $\begin{array}{l}\text { Proses: } \\
\text { Relasional }\end{array}$ & \multicolumn{2}{|l|}{ Atribut } \\
\hline \multirow[t]{2}{*}{17} & $\begin{array}{l}\text { [KOWE: SANG } \\
\text { DYAH AYU] }\end{array}$ & \multicolumn{4}{|c|}{ kaduga hanyrimpung } \\
\hline & [Aktor] $^{*}$ & \multicolumn{4}{|l|}{ Prosess: Material } \\
\hline \multirow[t]{2}{*}{18} & Jiwa ragaku & kok & \multicolumn{3}{|l|}{ kurung, } \\
\hline & Goal & Aktor & \multicolumn{3}{|l|}{ Prosess: Material } \\
\hline \multirow[t]{2}{*}{19} & kahormatan & \multicolumn{4}{|l|}{ mamprung } \\
\hline & Medium & Prosess: Material & & & \\
\hline 20 & [KAHORMATAN] & Rubuh & ngarep pinjung & & \\
\hline & [Medium]* $^{*}$ & Prosess: Material & Sirkumstan: Lokas & : Tempat & \\
\hline 21 & $\begin{array}{l}\text { Urip ana kutha } \\
\text { gedhe, }\end{array}$ & kowe & tak & tukokke & $\begin{array}{l}\text { omah sak } \\
\text { isine }\end{array}$ \\
\hline & $\begin{array}{l}\text { Sirkumstan: } \\
\text { Sebab: Tujuan }\end{array}$ & Klien & Aktor & Prosess: Material & Goal \\
\hline 22 & Kowe & $a b a$ & apa wae & & \\
\hline & Pembicara & Prosess: Verbal & Perkataan & & \\
\hline 23 & $\begin{array}{l}\text { nadyan } \\
\text { sesidheman }\end{array}$ & tak & mesthi (tak) wujt & dke & \\
\hline & $\begin{array}{l}\text { Sirkumstan: } \\
\text { Cara: Alat }\end{array}$ & Aktor & Prosess: Material & & \\
\hline
\end{tabular}

Struktur transitivitas bawa lagu campursari disusun atas enam proses material (klausa 1, 2, 3, 6, 7 dan 8), dua proses relasional (klausa 4 dan 5). Keenam proses material 
ini dilakukan oleh satu aktor, yaitu sang Dyah Ayu. Kedua proses relasional dalam bawa ini pun juga menghubungkan sang Dyah Ayu sebagai penyandang dengan atribut. Dengan demikian, konfigurasi transitivitas yang terdiri atas jenis proses beserta partisipan dan sirkumstan yang terkait menggambarkan state of doing (proses material) dan state of being (proses relasional) yang terkait dengan karakter kunci wanita, sang Dyah Ayu.

Konfigurasi transitivitas pada bagian isi lirik lagu campursari Sesidheman disusun atas sebelas proses material (klausa 9, 10,11, 12, 14, 17, 18, 19, 20, 21 dan 23), tiga proses relasional (klausa 13, 15, 16), dan satu proses verbal (klausa 22). Kesebelas proses material tersebut terdistribusi secara seimbang untuk mengungkapkan state of doing dengan aktor sang Dyah Ayu dan sang Pekik. Sebanyak lima klausa (klausa 9, 12, 17, 18, dan 21) digunakan pada klausa material dengan aktor Sang Dyah Ayu. Namun, tiga diantara lima aktor yang merujuk kepada sang Dyah Аyu ini tidak dinyatakan secara eksplisit (pada klausa 12, 17 dan 18), dan dua rujukan dinyatakan secara tidak langsung dengan menggunakan sufiks na pada verba patenana (klausa 9) dan pronomina kowe (klausa 21). Di sisi lain, kelima klausa material dengan aktor sang Pekik pun juga tidak merujuk sang Pekik secara langsung. Tiga klausa tidak meyebut aktor secara eksplisit (klausa 10, 19, dan 20), dan tiga klausa merujuk sang Pekik secara tidak langsung melaui penggunaan prefiks tak (klausa 11 dan 23) dan pronomina aku (klausa 14). Konfigurasi ini menunjukkan bahwa kedua karakter memiliki peran yang seimbang dalam skandal perselingkuhan. Perujukan kedua aktor secara implisit dan tidak langsung mengindikasikan bahwa pencipta lagu campursari Sesidheman tidak menuding secara langsung kepada karakter wanita maupun pria.

\section{Interpretasi teks}

Latar belakang penciptaan lagu Sesidheman ini berawal dari pemikiran si pencipta lagu terhadap fenomena kehidupan yang terjadi di masyarakat. Pencipta lagu ini melihat adanya perubahan pandangan masyarakat dalam menyikapi realitas hubungan asmara antara pria dan wanita, khususnya hubungan yang tidak resmi. Hubungan ini mengarah hubungan antara pria yang sudah sukses secara ekonomi dan wanita yang mempunyai kelebihan secara fisik. Sikap masyarakat terlihat lebih toleran dalam menyikapi hubungan tersebut. Bukti toleransi ini diantaranya adalah masyarakat sudah mulai bisa menerima orang yang melakukan perbuatan itu berbaur di masyarakat. Selain itu, para pelaku sudah tidak merasa malu atau risih lagi apabila perilakunya yang cenderung negatif tersebut diketahui oleh masyarakat. Melihat kondisi ini pencipta lagu ingin ikut andil memperlambat arus degradasi moral tersebut melalui lagu campursari yang berjudul Sesidheman.

Lagu ini dibuat setelah Sukron Suwondo sedang takziyah pada upacara pemakaman seorang temannya. Teringat akan kenangan dengan temannya yang sudah meninggal ini, Ki Sukron mencoba membuat lagu yang ditujukan untuk temannya tersebut, walaupun sebenarnya juga bisa ditujukan ke masyarakat luas karena adanya kesamaan peristiwa. Lagu ini dibuat pada hari Minggu di Taman Mini Indonesia Indah selepas dari takziyah pada upacara pemakaman temannya. Lirik lagu ini menggunakan kosa kata bahasa sastra yang indah yang menggambarkan seseorang yang sedang jatuh cinta, seperti kayungyun, angrungrung, ngincangake, sulistya, dan pinjung. Walaupun tema lagu tentang jatuh cinta, tetapi nuansanya terasa halus, tidak vulgar seperti lagu 
campursari yang lain misalnya Gubug Asmara, Bojo Loro, Lewung, dan Cucakrawa. Dalang kondang Ki Mantep Sudarsono menyebut lagu ini memiliki nilai sastra yang tinggi, walaupun berbicara tentang cinta namun tidak vulgar.

Selain kehalusan kosa katanya, lagu campursari ini juga memiliki keindahan dalam hal guru lagu yang sangat harmonis. Ini merupakan salah satu keahlian Ki Sukron Suwondo dalam menciptakan lagu campursari. Lagu Sesidheman ini terdiri dari empat pada. Setiap pada secara beraturan terdiri dari empat gatra dan masing-masing gatra terdiri dari 8-12 suku kata. Empat gatra di pada yang pertama berakhiran dengan guru lagu a; empat gatra di pada yang kedua berakhiran dengan guru lagu u; empat gatra di pada yang ketiga berakhiran dengan guru lagu ung; dan empat gatra yang terakhir berakhiran dengan guru lagu e. Hal ini menimbulkan keselarasan bunyi yang enak didengar. Tidak banyak lagu yang mempunyai keselarasan guru lagu mulai dari gatra pertama pada pertama sampai gatra terakhir pada pada terakhir.

Lagu campursari Sesidheman ini sangat populer di kalangan masyarakat Jawa Tengah dan Jawa Timur. Lagu ini banyak dinyanyikan di pentas wayang kulit, pada acara hajat mantu, ataupun pentas langsung lainnya. Di antara acara-acara tersebut yang sering mempopulerkan lagu Sesidheman yaitu melalui pentas wayang kulit. Sinden dan sekaligus dosen ISI Surakarta yang menyanyikan lagu campursari Sesidheman yaitu Sukesi Rahayu istri dari dalang Ki Cahyo Kuntadi dan Dwi Kurniati istri dalang Ki Anom Dwijo Kangko. Selain populer di acara-acara tersebut di atas, lagu Sesidheman juga banyak ditemukan di media sosial youtube dengan langgam atau versi yang berbeda-beda dengan penyanyi yang berbeda-beda pula.

Masyarakat pecinta lagu campursari sangat menyukai lagu Sesidheman. Hal ini terlihat dari banyaknya permintaan terhadap lagu ini untuk dinyanyikan di pentas hiburan di masyarakat baik dalam acara wayang kulit, tasyakuran, atau hajat mantu. Namun ada sebagian kecil masyarakat yang jeli dalam memperhatikan isi lagu dan merasa kurang setuju terhadap isi lagu, terutama pada bait pertama 'luwih becik patenana'. Mereka memaknai kalimat ini sebagai bentuk ekspresi orang jatuh cinta yang berlebihan sehingga dia akan melakukan apa saja agar cintanya terwujud.

\section{Lagu campursari Sesidheman sebagai praktik sosial}

Lagu campursari Sesidheman ini sebenarnya digunakan oleh penciptanya untuk merespon degradasi moral khususnya dalam hal hubungan asmara terselubung antara lelaki dan perempuan dalam konteks masyarakat Jawa pada umumnya, dan khususnya para pelaku seni yang dalam hal ini adalah dalang. Penciptaan lagu campursari Sesidheman ini pernah direspon oleh seorang dalang berkaliber nasional. Dalang tersebut menemui Ki Sukron Suwondo untuk menanyakan sebenarnya siapa orang yang digambarkan dalam lagu tersebut. Dalang tersebut bertanya dengan nada yang kurang menyenangkan, seolaholah dia merasa sebagai objek dalam lagu tersebut. Ki Syukron menjelaskan bahwa lagu tersebut sebenarnya ditujukan kepada temannya yang telah meninggal dunia. Respon dalang tersebut terhadap lagu campursari ini merefleksikan bahwa dalang tersebut memahami penggambaran praktik kurang baik yang terjadi dalam masyarakat. Reaksi dalang tersebut sedikit banyak merefleksikan reaksi atas suatu aksi (praktik) sebagaimana digambarkan dalam lagu campursari Sesidheman yang mungkin telah terjadi. 
Budaya Jawa memegang erat tata krama krama dan tata susila. Tata krama berkaitan dengan bagaimana seseorang menggunakan bahasa, sedangkan tata susila berkaitan dengan bagaimana seseorang berperilaku di dalam bergaul di masyarakat. Masyarakat Jawa sangat memegang erat adat yang menjadi warisan leluhurnya. Perilaku hubungan asmara antara lelaki dan perempuan yang tidak sah merupakan hal yang dulu sangat tabu di masyarakat Jawa. Seorang gadis yang hamil di luar nikah, dia akan diungsikan ke desa karena dianggap membuat malu keluarga. Namun sekarang ketaatan masyarakat dalam memegang kesusilaan sudah mulai mengendor. Sebagian masyarakat sudah tidak merasa malu lagi mempunyai anak gadis yang hamil di luar nikah. Bahkan kadang-kadang dijumpai dalam perhelatan perkawinan, perut pengantin putri sudah membesar atau hamil lebih dulu.

Ketaatan masyarakat Jawa dalam menjalankan aturan-aturan yang ada dalam budaya Jawa sudah mulai melemah. Hal ini dipengaruhi gaya hidup manusia jaman modern. Gaya hidup manusia jaman modern lebih mengutamakan material daripada nilainilai kesusilaan. Sebagian masyarakat akan memilih hidup dengan materi yang cukup walaupun harus melanggar norma susila yang ada di masyarakat. Masyarakat mulai permisif terhadap pelanggaran norma susila, dalam hal ini hubungan asmara tidak resmi antara pria dan wanita. Sebenarnya hal inilah yang dibidik oleh Ki Sukron Suwondo. Dia memotret kondisi penurunan nilai kesusilaan agar masyarakat menjadi sadar akan hal itu melalui karya lagu campursari Sesidheman.

\section{Pembahasan}

Lagu campursari Sesidheman ini disajikan dalam bentuk teks lirik yang terdiri atas dua bagian, yaitu Bawa dan isi lagu. Pada bagian bawa atau ringkasan, pencipta lagu menggambarkan awal mula terjadinya perselingkuhan antara seorang sinden dan dalang yang seolah-olah bukanlah hal yang tabu di mata masyarakat. Namun sebagai seorang dalang yang memahami nilai estetika, etika, dan moral, pencipta lagu ini menyampaikan pesannya dalam bentuk lirik lagu, dalam hal ini bawa, dengan tidak secara langsung menyebut sinden dan dalang sebagai pelaku utama. Sinden diungkapkan dengan metafora sang Dyah Ayu dan selendang kuning. Di sisi lain, dalang juga tidak disebut secara langsung, melainkan dengan menggunakan metafora sang Pekik seorang yang ahli budaya. Di dalam konteks dunia seni pentas wayang, penampilan seorang sinden identik dengan penampilan artis penyanyi yang tampil cantik, dan seorang dalang identik dengan pemeran utama yang tampil gagah dalam balutan busana Jawa. Hal ini melatarbelakangi digunakannya metafora sang Dyah Ayu, selendang kuning, dan sang Pekik yang ahli budaya.

Selain menggunakan metafora untuk menyebut karakter utama dalam lirik lagu campursari Sesidheman, pencipta lagu ini juga tidak menyebut kedua karakter secara langsung dan eksplisit, melainkan secara implisit dan tidak langsung. Penyebutan pelaku utama secara implisit dan tidak langsung dalam cerita yang dikemas dalam lirik lagu campursari ini menunjukkan bahwa pencipta lagu tidak ingin secara vulgar memaparkan orang-orang yang mungkin telah melakukan perselingkuhan sebagaimana digambarkan dalam lagu campursari Sesidheman.

Konfigurasi Tema-Rema pada bawa dan inti lirik lagu menunjukkan kohesi dan koherensi yang tinggi, dengan rujukan yang didistribusikan pada Tema dan Rema pada setiap klausa. Perujukan ini direalisasikan secara implisit dan tidak langsung. Namun jika 
dilihat dalam konteks yang utuh, rujukan Tema dan Rema pada klausa-klausa mengarah pada karakter wanita (sang Dyah Ayu) dan karakter pria (sang Pekik). Dalam konteks yang tercermin pada transitivitas, sang Dyah Ayu adalah seorang sinden yang bekerja pada sang Pekik, yang merupakan seorang dalang. Hal ini menunjukkan kepiawaian pencipta lagu dalam memaparkan sebuah fenomena sosial yang terjadi tanpa secara langsung menuding mereka yang disoroti melalui lirik lagu campursari ini. Pencipta lagu ini merealisasikan penggambaran state of doing dan state of being yang menggambarkan pengalaman dan dunia kedua karakter wanita dan pria dalam lagu campursari ini dengan transitivitas yang baik. Dengan demikian, mereka yang disoroti, yaitu orang-orang yang memiliki pengalaman dan dunia yang sama dengan apa yang digambarkan melalui transitivitas dalam lagu campursari ini tentu akan memahami maksud pencipta lagu ini. Penggunaan transitivitas yang baik ini membuat penyampaian pesan oleh pendipta lagu ini sangat halus dan tidak vulgar, sehingga orang-orang yang disoroti tentu akan bersikap dan berpikir sebagaiamana pesan dalam lagu ini disampaikan kepada mereka.

Di dalam menggambarkan peran karakter wanita dan pria dalam inti lirik lagu, pencipta lagu ini mendistribusikan klausa material secara imbang. Masing-masing karakter menjadi aktor pada lima klausa material dan karakter-karakter tersebut diungkapkan sebagai aktor secara implisit dan tidak langsung. Ini menunjukkan kesantunan dan ketidakberpihakan pencipta lagu dalam menggambarkan fenomena perselingkuhan antara pelaku seni yang dimaksud. Selain itu, konfigurasi distribusi klausa material yang seimbang ini menunjukkan bahwa pencipta lagu ingin mengatakan bahwa dalam fenomena perselingkuhan yang digambarkan alam lirik lagu campursari ini, kedua karakter memiliki peran yang seimbang dalam skandal perselingkuhan.

Fenomena kehidupan yang terjadi di masyarakat yang melatarbelakangi penciptaan lagu ini digambarkan secara halus dan seolah-olah merupakan sebuah roman percintaan dua orang gadis dan perjaka yang sedang tenggelam dalam asmara sehigga mereka lupa segalanya, termasuk status sosial dan status hukum mereka. Seorang dalang dalam masyarakat Jawa adalah seorang yang dipandang mumpuni dalam hal agama, budaya, dan berkehidupan bermasyarakat. Dengan demikian, dalang yang digambarkan telah mabuk asmara bak seorang yang masih belum berkeluarga semestinya akan segera sadar mengingat dia adalah seorang yang memahami norma, etika, dan agama. Pencipta lagu yang melihat adanya perubahan pandangan masyarakat dalam menyikapi realitas hubungan asmara antara pria dan wanita, khususnya hubungan yang tidak resmi ini menyampaikan ideologinya tentang norma, etika dan agama secara halus namun sangat mengena. Pilihan leksikal gramatikal dan cara mengungkapkan pesan dalam struktur Tema-Rema dan transitivitas dengan aktor yang disamarkan dalam lirik lagu ini akan ditangkap dengan jelas oleh target yang dibidik, yaitu para pelaku seni yang memahami seni, budaya dan bahasa Jawa. Dengan demikian, ideologi yang berupa pesan moral dalam lirik lagu campursari Sesidheman ini disampaikan dalam bingkai seni yang dan bahasa yang berterima bagi khalayak yang menjadi target dari ideologi yang ingin disampaikan.

\section{SIMPULAN}

Penyampaian ideologi dalam konteks masyarakat dengan tingkat status sosial dan norma budaya yang spesifik memerlukan cara dan pilihan bahasa yang tepat. 
Penyampaian ideologi dalam konteks masyarakat pelaku seni tentu juga harus disampaikan selaras dengan nilai budaya dan bahasa yang berlaku. Selain itu kesantunan bahasa baik dalam pilihan struktur Tema-Rema dan konfigurasi transitivitas juga menentukan keberterimaan pesan yang ingin disampaikan. Keberterimaan pesan ini merupakan kunci penetrasi ideologi, sebagaimana yang telah terjadi dalam lagu campursari Sesidheman. Pencipta lagu campursari ini berhasil memotret fenomena sosial tentang perselingkuhan di antara para pelaku seni dengan menggambarkannya secara jelas namun tanpa prasangka langsung sehingga para pelaku seni yang dibidik akan menangkap pesan yang disampaikan pencipta lagu dengan baik. Struktur Tema-Rema yang membangun kohesi dan koherensi yang kuat telah berhasil dikombinasikan dengan perujukan secara implisit sehingga secara konteks tetap terbangun makna yang jelas meskipun sebagian besar Tema tidak disebutkan secara eksplisit. Konfigurasi transitivitas yang baik yang digunakan pencipta lagu dalam menggambarkan fenomena perselinguhan dalam lirik lagu campursari Sesidheman telah berhasil memotret praktik sosial dan sekaligus menyisipkan ideologi untuk disampaikan pada kalangan masyarakat tertentu.

\section{DAFTAR PUSTAKA}

Chandra, A. A. (2017). Menilik aspek moral dalam lirik lagu campursari jawa timur: Sebuah kajian semiotika. Haluan sastra budaya. Jurnal ilmiah ilmu-ilmu humaniora. Vol 1:1.

Fairclough, N. (1995). Critical discourse analysis: The critical study of language. Harlow: Pearson.

Halliday, M.A.K. (1994). An introduction to functional grammar (2nd Ed). London: Edward Arnold.

Kress, G. (1990). Critical discourse analysis. Annual Review of Applied Linguistics 11:84-99.

Laksono, T. (2008). Menelusuri Karya dan Karsa Manthous sebagai Seniman dan dan Pencipta Campursari. Resital journal of performing arts. Vol 9:2.

Mazid, B. (1999). Ideology and control in some speech and newspaper genres: a Politicolinguistic approach to discourse analysis. Unpublished PhD dissertation, Cairo University, Egypt.

Sumarlam. (2013). Teori dan praktik analisis wacana. Surakarta: bukuKatta.

Supanggah, R. (2003). Campur sari: A reflection. Asian music. Vol. 34: 2. An Indonesian Issue. University of Texas Press.

Suranto, J. \& Santosa. (2019). Sistem pelarasan pada campursari. Dewa ruci. Jurnal pengkajian dan penciptaan seni. Vol 14: 1.

Van Dijk,T. A. (2008). "Critical discourse studies. A sociocognitif approach". In Discourse and practice New tools for critical discourse analysis, edited by R. Wodak and T. Van Leeuwen. Oxford: Oxford University Press.

Wadiyo, Haryono, T., Soedarsono, R.M., \& Ganap, V. (2011). Campursari manthous: Antara musik jenis baru dan fenomena sosial masyarakat pendukung. Harmonia. Journal of art and education. Vol 11:2. 
Wadiyo, Haryono, T., Soedarsono, R.M., \& Ganap, V. (2012). Campursari karya manthous: Kreativitas industri musik jawa dalam ruang budaya massa. Panggung. Jurnal seni budaya. Vol 22:4.

Wadiyo. (2002). Musik jawa campursari: Kajian tentang komposisi dan pembawaannya. Harmonia: Jurnal pengetahuan dan pemikiran seni. Vol. 3 No.1.

Wadiyo. (2004). Garapan campursari karya manthous. Harmonia: Jurnal pengetahuan dan pemikiran seni. Vol. 6 No.1.

Wellek, R. \& Warreb, A. (1977). Theory of literature. New York: Harourt, Brace and Company

Widiyono, Y. (2013). Nilai pendidikan karakter tembang campursari karya manthous. Jurnal pendidikan karakter.

Wiyoso, J. (2007). Campursari: Suatu bentuk akulturasi budaya dalam musik. Harmonia. Journal of arts research dan sducation. Vol 8:3. 


\section{SESIDHEMAN}

SECARA SEMBUNYI-SEMBUNYI

Bawa:

Intro:

Wiwitane, handherek sang pekik

Dimulai dari ketika (dia) ikut si tampan (untuk bekerja)

Priya bagus, kang olah budaya

Pria ganteng yang profesinya sebagai budayawan

Sowan menyang kutha gedhe

(Dia) pergi ke kota besar

Bendara terus kayungyun

Sang majikan pun tergoda

Selendhang kuning

(oleh) si wanita

Kang saking wukir

Yang datang dari gunung

Swara kurang premana

(Meskipun) suaranya kurang bagus

Ning wasis angungrung

Tapi (dia) pintar menggoda hati

Ngrungrung marang bendara

Menggoda hati sang majikan

Sang dyah ayu

Si wanita cantik ini

Pijer ngincangake alis

Selalu memainkan alis matanya menggoda

Trus tresna sesidheman

Lalu terjadilah perselingkuhan

Lirik:

Luwih becik patenana

Lebih baik kau bunuh aku

Timbang pepisahan mring dyah kang sulistya

Daripada (aku) harus berpisah dari (kamu) wanita yang cantik

Tak rewangi samudana marang kulawarga

Sampai aku harus sembunyi-sembunyi dari keluargaku

Garwa lan pra putra

(Dari) istri dan anak-anakku

\section{Liwat kincanging alismu}

Gerakan alismu yang menggoda

Kuwasa hangglandhang, rasaning atiku

Mampu membuat hatiku tergoda

Nadyan wus lingsir yuswaku

Meskipun aku sudah berusia lanjut

Aku isih mampu, ngladeni solahmu

Aku masih mampu mengimbangimu 


\section{Mangka kowe bocah nggunung}

Kamu memang anak dari gunung

Nadyan bocah nggunung, kaduga hanyrimpung

Meskipun dari gunung, kamu mampu menjerat hatiku

Jiwa ragaku kok kurung, kahormatan mamprung

Jiwa dan ragaku kau belenggu, kehormatanku hilang

Rubuh ngarep pinjung

Jatuh di depan wanita

Urip ana kutha gedhe

(Untuk) hidup di kota

Kowe tak tukokke omah sak isine

Kamu saya belikan rumah dan isinya

Kowe aba apa wae

Kamu minta apapun,

Nadyan sesidheman mesthi tak wujudke

Meskipun dengan sembunyi-sembunyi pasti aku penuhi 